\title{
Effect of Cichorium intybus L. on fatty liver induced by oxytetracycline in albino rats.
}

\author{
Eman G.E. Helal* , Samia M. Abd El-Wahab* , Atef M.Moussa Sharaf** \\ and Ghada A. Zedan* \\ *Zoology Department, Faculty of Science, Al-Azhar University, For Girls. \\ **Department of Physiology, Faculty of Medicine, Al-Azhar University
}

\begin{abstract}
Background: Fatty liver is now one of the most common diseases in Egypt. People prefer to use the medicinal plants instead of using chemical compounds because they are cheap and have few side effects compared to chemical compounds. The current investigation was carried out to examine the possible potential therapeutic and protective effects of Cichorium intybus (chicory) against oxytetracyclin-induced fatty liver in an attempt to understand its mechanism of action, which may pave the way for possible therapeutic applications.
\end{abstract}

Material and Methods: Albino rats were divided into two major groups, 15 rats for each. The first group was divided into three sub-groups: a) control, b) fatty liver group; that was injected intraperitonealy with oxytetracycline $(120 \mathrm{mg} / \mathrm{kg}$ ) for three consecutive days resulting in steatosis and c) chicory treated group; which was treated with chicory water extract $(70 \mathrm{mg} / \mathrm{kg}$ ) for 30 days after fatty liver induction. All animals were scarified after 33 days of the beginning of the experiment. The second group was divided into three subgroups: a) control, b) fatty liver group; that was injected intraperitonealy with oxytetracycline $(120 \mathrm{mg} / \mathrm{kg})$ for three consecutive days and c) drug protection group; which received chicory for 15 days before induction of fatty liver, then sacrificed after induction of fatty liver (3 days). Blood samples were collected for biochemical analysis. Liver specimens were obtained and fixed in $10 \%$ formalin for histological study.

Results: Fatty liver groups showed high significant increase in serum glucose, cholesterol, triglycerides, LDL cholesterol, ALAT, ASAT, GGT, LDH, urea, creatinine and A/G ratio while total protein, albumin, globulin and HDL cholesterol were significantly decreased compared to control group. These biochemical changes were accompanied with histopathological alterations in fatty liver tissue. The treatment with chicory ameliorated most of the evaluated biochemical parameters and improved the induced degenerative histopathological changes. The pretreatment with chicory before the induction of fatty liver gave some protection against factors that experimentally induced fatty liver.

Conclusion: Chicory as diet additive is recommend for fatty liver patients or those people who have hyperlipidemic family history.

Keywords: Fatty liver, Chicory, Lipid profile, Albino rats, Physiological parameters, Histopathology.

\section{Introduction:}

Any body organ is a potential target for injurious effects from chemicals but some organs are more vulnerable to adverse effects than others. The liver is often a target organ for a number of reasons. First, most toxicants enter the body via the gastrointestinal tract and after absorption they are carried by the hepatic portal vein to the liver. Thus the liver will be exposed to the highest concentrations of these chemicals (Reed, 1994; Lu, 1996). Chemicals encountered by other routes of 
exposure may also reach the liver through its blood supply from the hepatic artery as well as the portal vein (Stacey et al., 1993; Kulkarni and Byczkowski, 1994). Second, the liver has the ability to concenterates, biotransforms and excretes chemicals, irrespective of routes of exposure (Plaa and Hewitt, 1982).

Fatty liver is a reversible condition where large vacuoles of triglycerides accumulate in liver cells by the process of steatosis (Reddy and Rao, 2006). This condition can occur in diabetes mellitus, obesity, pregnancy and induced by certain drugs or toxins as tetracyclines and carbon tetrachloride (Araya, 2006). Fatty liver may results in cirrhosis and hepatocellular carcinoma (Ascha et al., 2010; Wong et al., 2010)

Tetracycline is one of a group of drugs known to induce micro vesicular steatosis when triglyceride accumulation was concomitant with the inhibition of mitochondrial lipid metabolism. (Amacher and Martin, 1997). Mechanisms by which tetracycline induces steatosis include the inhibition both of $\beta$-oxidation of free fatty acids and lipoprotein secretion from the liver (Letteron et al., 2003).

Recent researches have examined the effects of plants used to support liver functions and treat diseases in the liver. Chicory is a root vegetable whose green leafy part is often used in cooking or in salads. It has a long history of herbal use for its tonic effect upon the liver and digestive tract and as a cleaner for tract (Najafzadeh et al., 2011).

Previous studies on chicory extracts and formulations containing its roots or leaves revealed that, they produce hepatoprotective (Mitra et al., 2001; Ahmed et al., 2003 and Krylova et al., 2006), antihyperglycemic (Petlevski et al., 2003) and antioxidant effects (Sarawathy and Devi, 2001; Rossetto et al., 2005). In addition, chicory has anti-diabetic (Pushparaj et al., 2007), anti-bacterial, antimalarial (Petrovic et al., 2004) and gastroprotective (Gürbüz et al., 2002) activities. It is still used for its bitter-tonic, diuretic, digestive, lightly laxative and cholagogic properties, due to its content of mucilages, resins and bitter substances (Kalantari and Rastmanesh, 2009).

Fatty liver causes were markedly increased in Egyptian people throughout last years. The present study aims to examine the possible potential therapeutic and protective effects of chicory against fatty liver. It investigates also its effect on the functions of some vital organs as liver, kidney and heart.

\section{Material and Methods:}

\section{Chemicals:}

-Fresh chicory roots were obtained from the farm and crushed to fine pieces, then mixed with distilled water $15 \mathrm{mg} / 100 \mathrm{ml}$ for 50 minutes at $70^{\circ} \mathrm{C}$ with continuous stirring and then filtered (Meehye and Hyun, 1998). -Oxyteracycline was obtained from El-Nile Pharmaceutical Company (Cairo, Egypt).

\section{Experimental design:}

Thirty female albino rats of local strain weighting 150-200 g. were obtained from El-Nile Pharmaceutical Company (Cairo, Egypt). All rats were fed on balanced diet and water and allowed to be acclimatized for 10 days before the beginning of the experiment. The animals were housed in metal cages (5 per cage) and maintained under prevailing atmospheric conditions with continuous cleaning and observation.

The rats were divided into two groups; the first group was to follow up the effect of chicory as curative plant for fatty liver, while the second group was to illustrate the effect of this plant as protective agent against fatty liver. Each group was subdivided into three subgroups.

\section{The first group was divided into:}

1- Control group:

Five rats were injected intraperitonealy with saline $(120 \mathrm{mg} / \mathrm{kg})$ for three consecutive days.

2- Oxytetracycline group: 
Five rats were injected intraperitonealy with oxytetracycline $(120 \mathrm{mg} / \mathrm{kg})$ for three consecutive days for fatty liver induction (Nicola et al., 1996).

3- Chicory curative group:

Five rats were injected intraperitonealy with oxytetracycline $(120 \mathrm{mg} / \mathrm{kg})$ for three consecutive days then administered chicory extract $(75 \mathrm{mg} / \mathrm{kg})$ daily by gastric tube for 30 days, as a food supplement.

All animals were sacrificed after 33 days of the beginning of the experiment.

\section{The second group was divided into:}

1- Control group:

Five rats were injected intraperitonealy with saline $(120 \mathrm{ml} / \mathrm{kg})$ for three consecutive days then sacrificed.

2- Oxytetracycline group:

Five rats were injected intraperitonealy with oxytetracycline $(120 \mathrm{mg} / \mathrm{kg})$ for three consecutive days for fatty liver induction then sacrificed.

3- Chicory Protection group:

Five rats were administered chicory extract $(70 \mathrm{mg} / \mathrm{kg}$ ) daily by gastric tube for 15 days, then intraperitonealy injected with oxytetracycline $(120 \mathrm{mg} / \mathrm{kg})$ for three consecutive days, then were sacrificed.

\section{Blood sampling:}

The animals were anesthetized under light ether anesthesia, blood samples were collected then all animals were scarificed. Blood samples were kept for 30 minutes without disturbance then centrifuged for 15-20 minutes at $5000 \mathrm{rpm}$ to separate serum.

\section{Biochemical assays:}

Serum glucose was estimated according to enzymatic colorimetric method described by Tietz (1986). Alanine amino transferase (ALAT) and aspartate amino transferase (ASAT) were determined by the method of Breuer (1996). Serum $\gamma$-glutamyl transferase (GGT) was performed by kinetic method according to Persijn and Slik (1976). Serum total protein was estimated according to Doumas (1975). Serum albumin was determined according to the method of Dumas et al. (1997). The globulin value for each sample was obtained by substracting the albumin value from the corresponding total protein value. The $A / G$ ratio for each sample was obtained by dividing the albumin level to globulin level. Total lipids were assayed by the method of Kaplan (1984). Serum total cholesterol (T.C) was performed according to Henry et al. (1974). Serum triglycerides (T.G) were determined according to the method of Fossati and Prencie (1982). Serum high density lipoproteins cholesterol (HDL-cholesterol) was assayed according to Burstein (1970). The concentration of low density lipoproteins cholesterol (LDLcholesterol) in serum was estimated by the equation used by Friedewald et al. (1972) as follow:

$\mathrm{LDL}$ - cholestero $1(\mathrm{mg} / \mathrm{dl})=$

Total cholestero $1-$ HDL cholestero $1-\left(\frac{\text { T.G }}{5}\right)$

Measurement of serum urea was done according to the method of Patton and Crouch (1977). Serum creatinine was evaluated according to the method of Jaffe (1986).

\section{Histological examination:}

For light microscopy, the liver was surgically removed from the rats at the end of each experimental period, fixed in $10 \%$ neutral buffered formalin, embedded in paraffin wax, sectioned at $5 \mu \mathrm{m}$ and stained with hematoxylin and eosin (Harris, 1900).

\section{Statistical Analysis:}

The results were expressed as mean \pm standard error (SE). The significance of differences between means was measured by student's t-test (Snedecor and Cochran, 1980). The $P$ values below 0.05 were considered significant.

\section{Results:}

\section{a- Biochemical studies}

The data represented in table (1) showed high significant increase $(\mathrm{P} \leq 0.01)$ in serum glucose level in fatty liver group when compared with control group. Treatment of rats with chicory for 30 days after induction of fatty liver with oxytetracycline caused 
insignificant change in serum glucose level when compared with control group, while it showed high significant decrease $(\mathrm{P} \leq 0.01)$ when compared with fatty liver group. On the other hand, giving chicory for 15 days as a protective agent before induction of fatty liver was associated with hyperglycemia in rats when compared with control group but with a mild manner than the fatty liver groups.

A highly significant increase $(\mathrm{P} \leq 0.01)$ in serum total lipids, triglycerides and LDLcholesterol was recorded in fatty liver group, while HDL-cholesterol was significantly decreased in the same group when compared with the control animals (Table 2).

Induction of fatty liver followed by treatment with chicory for 30 days ameliorated the effect of oxytetracycline on serum cholesterol, triglycerides and LDLcholesterol when compared with control and fatty liver groups, while recorded high significant increase $(\mathrm{P} \leq 0.01)$ in serum total lipids when compared with control group but decreased from the fatty liver group in a highly significant manner $(\mathrm{P} \leq 0.01)$.

Treatment of rats with chicory as a protective agent reduced greatly $(\mathrm{P} \leq 0.01)$ the elevation induced by oxytetracycline in total lipids and triglycerides but these parameters remained higher than the corresponding controls in a highly significant manner $(\mathrm{P} \leq 0.01)$. Regarding to cholesterol, significant increase $(\mathrm{P} \leq 0.05)$ was recorded in comparison with the control group but the recorded value was lower than the fatty liver group in a significant manner $(\mathrm{P} \leq 0.05)$. Chicory also significantly reduced the elevated level of LDL but it didn't affect HDL reduction which was caused by oxytetracycline in comparison with control rats.

Table (3) showed that, fatty liver group recorded high significant decrease $(\mathrm{P} \leq 0.01)$ in serum total protein, albumin and globulin while $A / G$ ratio was significantly increased $(\mathrm{P} \leq 0.01)$ when compared with control group.
Treatment of rats with chicory for 30 days after induction of fatty liver was ameliorated oxytetracycline effects on serum total protein, albumin, globulin and $\mathrm{A} / \mathrm{G}$ ratio when compared with control group.

On the same trend, giving chicory to rats for 15 days as a protective agent before induction of fatty liver ameliorated the effect of oxytetracycline on protein profile.

In respect to serum enzymes (ALAT, ASAT, GGT and LDH), fatty liver group showed high significant increase $(\mathrm{P} \leq 0.01)$ in the activities of these enzymes when compared with control group (Table 4).

Subjecting of rats to chicory for 30 days after induction of fatty liver recovered ASAT and GGT activities to normal values and ameliorated serum ALAT and LDH activities where the animals of this group recorded high significant decrease when compared with fatty liver group.

Giving chicory for 15 days before induction of fatty liver reduced the effect of oxytetracycline on ASAT, GGT and LDH when compared with fatty liver group but the activities of these enzymes still elevated in a highly significant manner $(\mathrm{P} \leq 0.01)$ from the corresponding controls. On the other hand, subjected rats to chicory as protective agent did not affect the activity of serum ALAT.

Table (5) showed high significant increase $(\mathrm{P} \leq 0.01)$ in serum urea and creatinine in fatty liver group when compared with control group.

Chicory treated group recorded high significant increase $(\mathrm{P} \leq 0.01)$ in serum urea and creatinine when compared with control group but it showed high significant decrease $(\mathrm{P} \leq 0.01)$ in serum urea and creatinine when compared with fatty liver group.

On the other hand, giving chicory before induction of fatty liver ameliorated the 
effect of oxytetracycline on serum urea and creatinine.

\section{b- Histopathological studies:}

The liver of control rats was formed of the classic hepatic lobules. Each lobule showed radially arranged hepatocytes forming cords around the central vein. Hepatocytes appeared polygonal in shape with rounded vesicular nuclei. Blood sinusoids were seen separating the cords of the liver cells and lined by flattened endothelial cells and von Kupffer cells (Plate 1A).

Examination of liver sections of rats injected with oxytetracycline for three consecutive days showed apparent enlargement of hepatocytes reaching to ballooning. Cells all over the hepatic lobule were seen to contain mainly macro vacuoles dispersed throughout the cytoplasm. Some cells were seen having one large vacuole filling the whole cell with thin rim of cytoplasm around and pushing the nucleus to one side. Other cells contained smaller vacuoles with either central or eccentric nuclei (Plate 1B).

After one month recovery period from oxytetracycline injection, many fat vacuoles, ballooned hepatocytes and apoptosis were abundant (Plate 1C).

After treatment with oxytetracycline for three consecutive days and chicory for one month, liver lobular morphology was almost similar to the control (Plate 1D).

Sections from rats treated with chicory root extract for 15 days before fatty liver induction demonstrated many small fat vacuoles and congested hepatic sinusoids (Plate 1E).

Table (1): Effect of chicory on serum glucose level in treated and protected groups:

\begin{tabular}{|c|c|c|c|c|c|c|c|}
\hline & & \multicolumn{3}{|c|}{ Treated group } & \multicolumn{3}{|c|}{ Protected group } \\
\hline & & 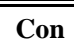 & 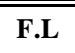 & 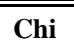 & 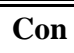 & 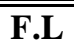 & $\overline{\text { Chi }}$ \\
\hline \multirow{4}{*}{$\begin{array}{c}\text { Serum } \\
\text { Glucose } \\
\text { level } \\
(\mathrm{mg} / \mathrm{dl})\end{array}$} & Mean & 74.1 & 95.0 & 76.0 & 74.9 & 96.1 & 91.3 \\
\hline & $\pm \mathrm{SE}$ & 1.48 & 1.22 & 1.34 & 1.4 & 1.3 & 1.3 \\
\hline & P1 & & $* *$ & N.S & & $* *$ & $* *$ \\
\hline & $\mathbf{P 2}$ & & & $* *$ & & & $* *$ \\
\hline
\end{tabular}

Each value is the mean of 5 animals \pm SE.

N.S: non significant.

$*$, **: is the significant difference when compared at $\mathrm{P} \leq 0.05$ and $\mathrm{P} \leq 0.01$ respectively.

$\mathrm{P} 1$ : in comparison with control group.

$\mathrm{P} 2$ : in comparison with fatty liver group. 
Table (2): Effect of chicory on serum lipid profile (total lipids, triglycerides, cholesterol, LDL and HDL) in treated and protected groups:

\begin{tabular}{|c|c|c|c|c|c|c|c|}
\hline & & \multicolumn{3}{|c|}{ Treated group } & \multicolumn{3}{|c|}{ Protected group } \\
\hline & & Con & $\overline{\text { F.L }}$ & Chi & Con & $\overline{\text { F.L }}$ & $\overline{\text { Chi }}$ \\
\hline \multirow{4}{*}{$\begin{array}{c}\text { Total Lipids } \\
\text { (mg/dL) }\end{array}$} & Mean & 309 & 411.4 & 336.2 & 306.2 & 408.8 & 397.6 \\
\hline & $\pm \mathrm{SE}$ & 2.7 & 2.1 & 2.4 & 2.1 & 1.6 & 1.3 \\
\hline & P1 & & $* *$ & $* *$ & & $* *$ & $* *$ \\
\hline & $\mathbf{P 2}$ & & & $* *$ & & & $* *$ \\
\hline \multirow{4}{*}{$\begin{array}{c}\text { Triglycerides } \\
\text { (mg/dl) }\end{array}$} & Mean & 42.4 & 90.4 & 46.7 & 41.3 & 89.5 & 80.6 \\
\hline & $\pm \mathrm{SE}$ & 1.9 & 1.4 & 1.5 & 1.1 & 1.3 & 1.2 \\
\hline & P1 & & $* *$ & N.S & & $* *$ & $* *$ \\
\hline & P2 & & & $* *$ & & & $* *$ \\
\hline \multirow{4}{*}{$\begin{array}{c}\text { Cholesterol } \\
\text { (mg/dl) }\end{array}$} & Mean & 95.8 & 104.5 & 96.6 & 94.6 & 106.1 & 99 \\
\hline & $\pm \mathrm{SE}$ & 1.5 & 1.5 & 1.3 & 1.4 & 1.8 & 1.5 \\
\hline & P1 & & $* *$ & N.S & & $* *$ & $*$ \\
\hline & P2 & & & $* *$ & & & $*$ \\
\hline \multirow{4}{*}{$\begin{array}{c}\text { LDL } \\
\text { (mg/dl) }\end{array}$} & Mean & 40.6 & 48.02 & 42.3 & 38.5 & 48.1 & 43.76 \\
\hline & $\pm \mathrm{SE}$ & 2.88 & 1.4 & 1.1 & 1.3 & 1.4 & $\mathbf{0 . 8 8}$ \\
\hline & P1 & & $*$ & N.S & & $* *$ & $* *$ \\
\hline & $\mathbf{P 2}$ & & & $*$ & & & $*$ \\
\hline \multirow{4}{*}{$\underset{(\mathrm{mg} / \mathrm{dl})}{\text { HDL }}$} & Mean & 46.7 & 38.4 & 45.0 & 47.8 & 39.9 & 39.1 \\
\hline & $\pm \mathrm{SE}$ & 1.6 & 1.2 & 1.4 & 1.3 & 1.4 & 1.3 \\
\hline & P1 & & $* *$ & N.S & & $* *$ & $* *$ \\
\hline & P2 & & & $* *$ & & & N.S \\
\hline
\end{tabular}

Each value is the mean of 5 animals \pm SE.

N.S: non significant.

$*$, **: is the significant difference when compared at $\mathrm{P} \leq 0.05$ and $\mathrm{P} \leq 0.01$ respectively.

$\mathrm{P} 1$ : in comparison with control group.

$\mathrm{P} 2$ : in comparison with fatty liver group. 
Table (3): Effect of chicory on serum protein profile (total proteins, albumin, globulin and $\mathrm{A} / \mathrm{G}$ ratio) in treated and protected groups:

\begin{tabular}{|c|c|c|c|c|c|c|c|}
\hline & & \multicolumn{3}{|c|}{ Treated group } & \multicolumn{3}{|c|}{ Protected group } \\
\hline & & Con & F.L & $\overline{\text { Chi }}$ & Con & F.L & $\overline{\text { Chi }}$ \\
\hline \multirow{4}{*}{$\begin{array}{l}\text { Total Protein } \\
\text { (g/dl ) }\end{array}$} & Mean & $\overline{7.5}$ & 5.7 & 7.6 & 7.6 & 5.3 & 6.1 \\
\hline & $\pm \mathrm{SE}$ & 0.08 & 0.09 & 0.1 & 0.1 & 0.08 & 0.1 \\
\hline & P1 & & $* *$ & N.S & & $* *$ & $* *$ \\
\hline & P2 & & & $* *$ & & & $* *$ \\
\hline \multirow{4}{*}{$\begin{array}{l}\text { Albumin } \\
\text { ( g/dl ) }\end{array}$} & Mean & $\overline{4.4}$ & 3.8 & 4.6 & 4.5 & 3.6 & 3.9 \\
\hline & $\pm \mathrm{SE}$ & 0.1 & 0.08 & $\mathbf{0 . 0 7}$ & 0.1 & 0.08 & 0.09 \\
\hline & P1 & & $* *$ & N.S & & $* *$ & $* *$ \\
\hline & P2 & & & $* *$ & & & $*$ \\
\hline \multirow{4}{*}{$\begin{array}{l}\text { Globulin } \\
\text { ( g/dl ) }\end{array}$} & Mean & 3.1 & 1.9 & 2.9 & 3.1 & 1.7 & 2.2 \\
\hline & $\pm \mathrm{SE}$ & 0.08 & 0.08 & 0.1 & 0.06 & 0.08 & 0.1 \\
\hline & P1 & & $* *$ & N.S & & $* *$ & $* *$ \\
\hline & $\mathbf{P 2}$ & & & $* *$ & & & $* *$ \\
\hline \multirow{4}{*}{ A/G ratio } & Mean & 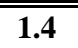 & 2.1 & 1.6 & 1.5 & 2.1 & 1.8 \\
\hline & $\pm \mathrm{SE}$ & 0.07 & 0.1 & 0.07 & 0.05 & 0.14 & 0.1 \\
\hline & P1 & & $* *$ & N.S & & $* *$ & $*$ \\
\hline & P2 & & & $* *$ & & & N.S \\
\hline
\end{tabular}

Each value is the mean of 5 animals \pm SE.

N.S: non significant.

$*$, **: is the significant difference when compared at $\mathrm{P} \leq 0.05$ and $\mathrm{P} \leq 0.01$ respectively.

$\mathrm{P} 1$ : in comparison with control group.

$\mathrm{P} 2$ : in comparison with fatty liver group. 
Table (4): Effect of chicory on serum enzyme activities (ASAT, ALAT, GGT, LDH) in treated and protected groups:

\begin{tabular}{|c|c|c|c|c|c|c|c|}
\hline & & \multicolumn{3}{|c|}{ Treated group } & \multicolumn{3}{|c|}{ Protected group } \\
\hline & & 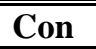 & F.L & $\begin{array}{l}\text { Chi } \\
\end{array}$ & 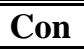 & F.L & Chi \\
\hline \multirow{4}{*}{$\begin{array}{l}\text { ASAT } \\
(\mathbf{U} / \mathbf{m l})\end{array}$} & Mean & 94.7 & 124.7 & 96.2 & 95.1 & 126.1 & $\overline{120.8}$ \\
\hline & $\pm \mathrm{SE}$ & 1.1 & 1.38 & 1.34 & 1.02 & 1.64 & 1.27 \\
\hline & P1 & & $* *$ & N.S & & $* *$ & $* *$ \\
\hline & P2 & & & $* *$ & & & $*$ \\
\hline \multirow{4}{*}{$\begin{array}{l}\text { ALAT } \\
(\mathbf{U} / \mathbf{m l})\end{array}$} & "Mean & 49.3 & 94.7 & $\begin{array}{c}69.4 \\
\end{array}$ & $\begin{array}{l}49.6 \\
\end{array}$ & 96.5 & 91.6 \\
\hline & $\pm \mathrm{SE}$ & 1.71 & 1.55 & 2.4 & 1.63 & 1.56 & 1.79 \\
\hline & P1 & & $* *$ & $* *$ & & $* *$ & $* *$ \\
\hline & P2 & & & $* *$ & & & N.S \\
\hline \multirow{4}{*}{$\begin{array}{c}\text { GGT } \\
(\mathbf{I u} / \mathbf{L})\end{array}$} & בMean & 10.04 & 21.34 & $\begin{array}{l}10.1 \\
\end{array}$ & $\begin{array}{l}10.7 \\
\end{array}$ & 21.1 & $\overline{14.0}$ \\
\hline & $\pm \mathbf{S E}$ & 0.33 & 0.73 & 0.11 & 0.26 & 0.69 & 0.13 \\
\hline & P1 & & $* *$ & N.S & & $* *$ & $* *$ \\
\hline & P2 & & & $* *$ & & & $* *$ \\
\hline \multirow{4}{*}{$\begin{array}{c}\text { LDH } \\
(\mathbf{U} / \mathbf{L})\end{array}$} & "Mean & $\overline{179}$ & 523 & 263 & 185 & $\overline{505}$ & 400 \\
\hline & $\pm \mathbf{S E}$ & 2.75 & 3.48 & 2.5 & 2.15 & 4.18 & 2.76 \\
\hline & P1 & & $* *$ & $* *$ & & $* *$ & $* *$ \\
\hline & P2 & & & $* *$ & & & $* *$ \\
\hline
\end{tabular}

Each value is the mean of 5 animals \pm SE.

N.S: non significant.

*, **: is the significant difference when compared at $\mathrm{P} \leq 0.05$ and $\mathrm{P} \leq 0.01$ respectively.

P1: in comparison with control group.

$\mathrm{P} 2$ : in comparison with fatty liver group.

Table (5): Effect of chicory on serum urea and creatinine in treated and protected groups.

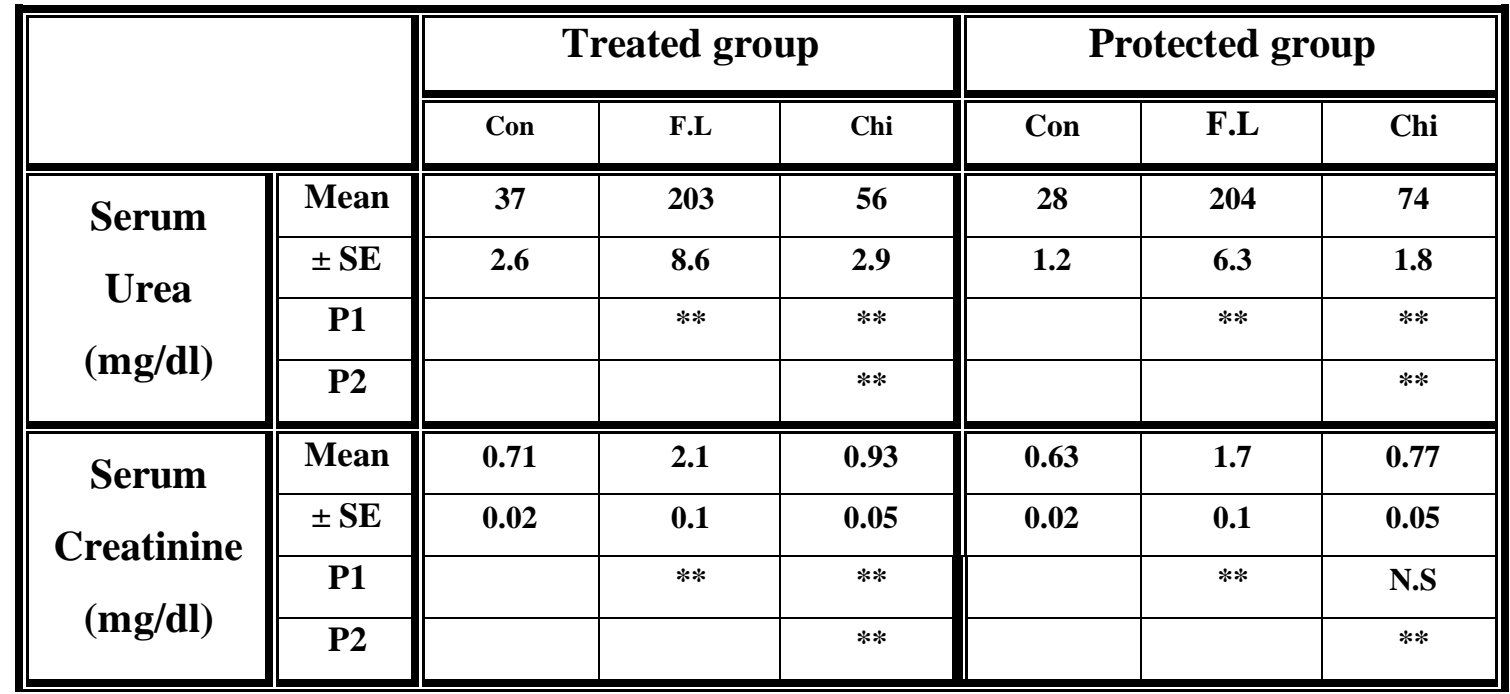

Each value is the mean of 5 animals \pm SE.

N.S: non significant.

*, **: is the significant difference when compared at $\mathrm{P} \leq 0.05$ and $\mathrm{P} \leq 0.01$ respectively.

P1: in comparison with control group.

$\mathrm{P} 2$ : in comparison with fatty liver group. 

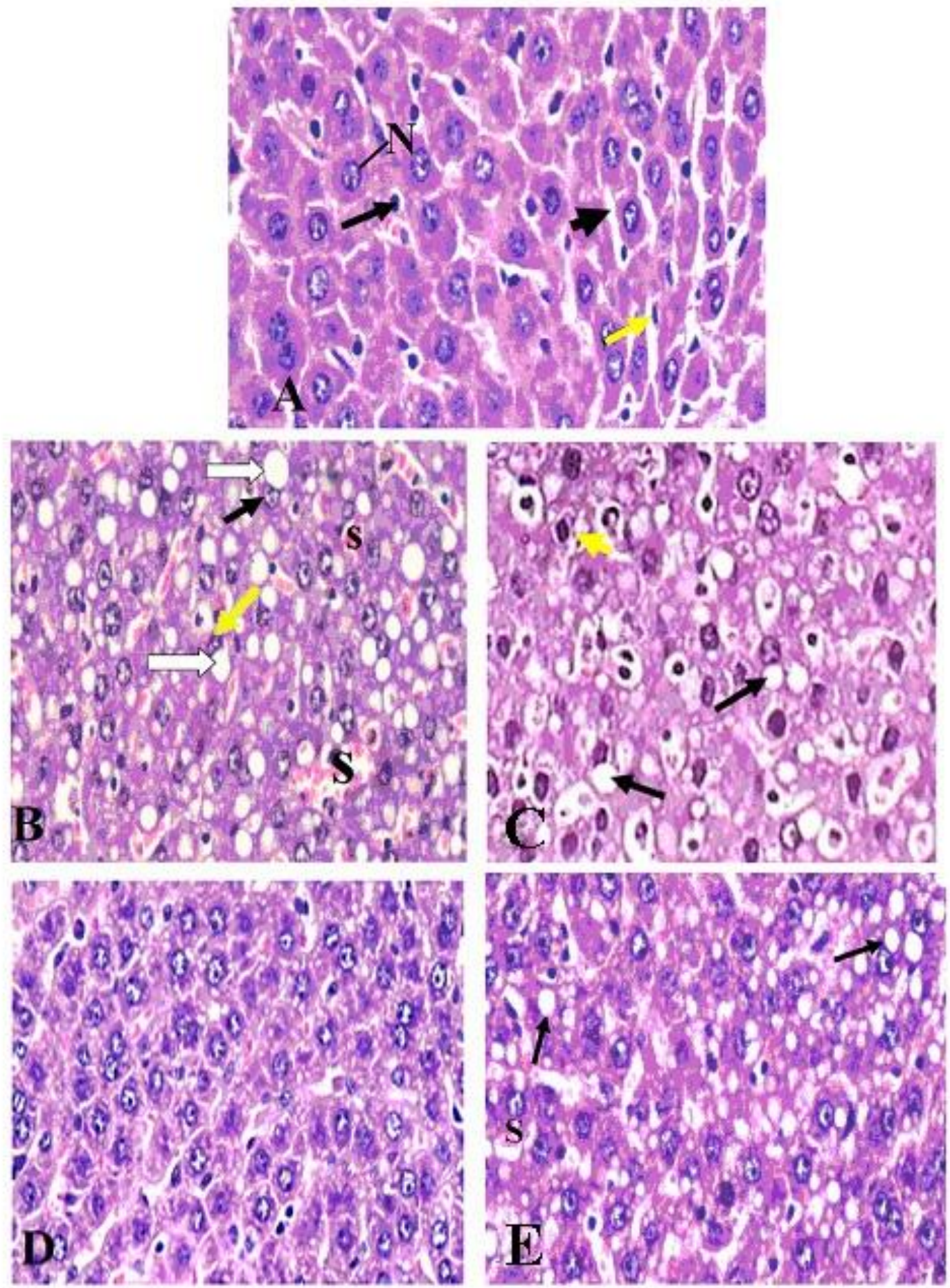

Plate 1: Photomicrograph of sections in livers of the examined rats (H \& E, X 400). A: Control, showing cords of hepatocytes separated by blood sinusoids (black arrow) lined by flat endothelial (arrow head) and von Kupffer (yellow arrow) cells. The hepatocytes show vesicular nuclei (N) and granular cytoplasm. B: After treatment with oxytetracycline for three consecutive days, displaying fatty liver as indicated by many vacuoles (white arrow), which occupy almost all the cytoplasm of hepatocytes, displacing nucleus (yellow arrow) to periphery. Dilated congested blood sinusoids (S) are also seen. C: After treatment with oxytetracycline for three consecutive days and then recovery after one month, showing many fatty vacuoles (arrows), ballooned hepatocytes and apoptosis (arrow head). D: After treatment with oxytetracycline for three consecutive days and chicory for one month, displaying that the architecture of most hepatocytes was nearly similar to control. No vacuoles were detected all over the lobule E: After treatment with chicory for 15 days and then injection with oxytetracycline for three consecutive days, demonstrating many fat vacuoles (arrows) and congested blood sinusoids $(\mathbf{S})$. 


\section{Discussion}

Nonalcoholic fatty liver disease (NAFLD) is believed to be a feature of metabolic syndrome because it is closely associated with visceral obesity, dyslipidaemia, insulin resistance, and type 2 diabetes mellitus (Angulo, 2002). Fatty liver causes were markedly increased in Egyptian people throughout last years. This high prevalence of NAFLD is probably problematic because patients with NAFLD show higher all-cause mortality and increased risks for liverrelated death and cardiovascular disease (Adams et al., 2005; Arslan et al., 2007). The present study was conducted to evaluate the beneficial effect of chicory on fatty liver status induced by oxytetracycline in albino rats.

In this study, oxytetracycline induced hyperglycemia which may be attributed to its inhibitory action on the absorbing function of the intestine and the retarded glucose utilization in the tissues (Storozhuk and Shamsutdinova, 1981). Treating rats with chicory turned glucose level back to normal value. The improvement in glycemic status may be due to inulin (active substance of chicory) which modulate the hormonal level of insulin and glucagons, thereby regulating carbohydrate and lipid metabolism by lowering serum glucose level (Narinder and Anil, 2002).

The experimental results revealed that, the hyperlipidemic effect of oxytetracycline was ameliorated with the treatment of rats with chicory. The effect of chicory on lipid profile may be due to the main active compounds of chicory root extract, inulin, which is a polymer of fructose with B (1-2) glycosidic linkage (Kocsis et al., 2003; Wight and Niekerk, 1983). Inulin can cause alteration of hormone secretion which affect lipid metabolism. In accordance with the present results, Yassin and El-Hadidy (2007) reported that, chicory extract improved lipid profile by lowering plasma total cholesterol and triglyceride concentrations. These results were in agreement with those reported by Abd ElGhanny et al. (2007) who stated that, dietary fibres inhibit cholesterol accumulation in blood and enhance resistance of vascular walls. The cholesterol-lowering effect of dietary fibres may be related to its viscosity-raising properties, which could reduce fat and cholesterol absorption or bile acid reabsorption from the gastrointestinal tract. In addition, Kim and Shin (1998) reported that chicory increase the inulin in serum. Inulin has been found to decrease the serum triglycerides in rats due to decrease synthesis of triglyceride in the liver. Keys (1980) recorded that, HDLc transports cholesterol from tissues to the liver for excretion into bile. The improved lipid metabolism which observed in rats fed chicory may be due to an alteration in the absorption and/or synthesis of cholesterol which might result from the changes in cecal fermentation and by an increase in fecal excretion of lipids, cholesterol and bile acids (Kim and Shin, 1998).

Estimation of the activity of ALAT, ASAT and GGT are good marker of assessment liver functions. These enzymes are normally located in the cytosol of hepatocytes. When liver cells are damaged, these enzymes are released in the plasma and their increased activity in plasma is a useful marker of the extent and type hepatocellular damage (Atta et al., 2010).

Treatment of rats with oxytetracycline for three consecutive days induced fatty liver, necrosis and inflammation. These histological changes were associated with the high significant increase in activities of serum ALAT, ASAT, GGT and LDH.

In the present study, the protective effects of chicory on ALAT and ASAT are in agreement with Ahmed et al. (2009) who reported that, treatment of rats with chicory caused a reduction of ALAT and ASAT activities. This reduction may be due to the presence of isoflavones, polyphenoles and other antioxidants which aided in reducing the liver injury. This protective effect of chicory was also proven by the histological examination of the liver.

The antioxidant properties of Cichorium intybus were evaluated by Gazzani et al. 
(2000) in vitro as antioxidant activity and in vivo as protective activity against rat liver cell microsome lipid peroxidation. The obtained results proved that chicory contained both biological antioxidant and prooxidant compounds.

Moreover, reduced fat droplets in the liver as a result of reducing body weight may also improve liver functions. In accordance with the present study, chicory has antihepatotoxic effect and significantly lower serum levels of ASAT and ALAT enzymes even in $\mathrm{CCL}_{4}$ intoxicated rats (Zafar and Mujahed, 1998; Mitra et al., 2001; Ahmed et al., 2003). In this concern, it was reported that, chicory root extract therapy leads to normalization of some morphofunctional liver features (decreases glycogen content and cell necrosis) in rats with $\mathrm{CCl}_{4}$-induced hepatitis (Krylova et al. 2006; kim et al. 2002).

The antioxidant, anti-inflammatory and free radical scavenging properties of chicory were ameliorated the effect of oxytetracycline on serum LDH activity through scavenge the free radicals, minimize lipid peroxidation, thereby preventing membrane damage and leakage of enzymes (Suchalatha and Shyamala, 2004).

The present results clearly demonstrate the marked antihepatotoxic effects of chicory extract. This fact is based on the tendency of liver enzymes, glucose and triglycerides to return towards levels of the control group in addition to regeneration of hepatic cells, as shown by histological examination.

Previous studies have demonstrated that chicory (Ahmed et al., 2003; Krylova et al., 2006) exhibited hepatoprotective effect. In the present study, chicory exhibited a hepatoprotective effect which was more effective in reducing serum liver enzymes towards or even below the normal values. The decreased liver enzymes below the oxytetracycline-treated or normal rats are probably due to a membrane stabilizing effect.
Serum total protein, albumin and globulin were decreased in fatty liver group, while A/G was increased. This decrease could be related to hepatic dysfunction and decreased protein synthesis. Also it may be due to either damage of vital biological processes or to changes in permeability of liver, kidney and other tissue cells leading to leakage of protein via the kidney (Roushdy et al., 1989). Administration of chicory after fatty liver induction was tolerated the hypoproteinemic effect of oxytetracycline due to its beneficial effect on liver and kidney functions.

Treating rats with oxytetracycline caused kidney dysfunction which appeared through high increase in serum urea and creatinine. The present study revealed that, administration of chicory to fatty liver rats reduced and normalized the levels of plasma creatinine and urea. On the other hand, the pre-treatment with this plant before the induction of fatty liver inhibited the higher increase of plasma creatinine and urea but they did not normalized them. The decrease in serum urea and creatinine with chicory administration may be due to the higher antioxidant activities of chicory. This obtained result was in agreement with Fortin (2004) who reported that, the medicinal herb, chicory, exhibited antioxidant activity and contained significantly higher levels of phenolics.

\section{References:}

Abd El-Ghanny M, Farouk M, Mohamed A, Hatem M and Hanaa F (2007): Effect of some vegetables intake on the precarcinogenic risk resulting from extreme grilled meat on experimental rats. Basic Clinical Pharmacology Toxicology, 97: 958-982.

Adams LA, Lymp JF, St Sauver J, Sanderson SO, Lindor KD, Feldstein A and Angulo P. (2005): The natural history of nonalcoholic fatty liver disease: a population-based cohort study. Gastroenterology, 129 (1): 113-121.

Ahmed B, Al-Howiriny T and Siddiqui A (2003): Antihepatotoxic activity of seeds of Cichorium intybus. J. Ethnopharmacol., 87 (2-3): 237- 240.

Ahmed L, Ramadan R and Mohamed R (2009): Biochemical and histopathological studies on the water extracts of marjoram and chicory herbs and their mixture in obese rats. Pakistan Journal of Nutrition, 8 (10): 1581-1587. 
Amacher D and Martin B (1997): Tetracyclineinduced steatosis in primary canine hepatocyte cultures. Fundam. Appl. Toxicol., 40: 256-263.

Angulo P. (2002): Nonalcoholic fatty liver disease. N. Engl. J. Med., 346 (16): 1221-1231.

Araya Q (2006): Glucose tolerance alterations and frequency of metabolic syndrome among patients with nonalcoholic fatty liver disease. Rev. Med. Chil., 134 (9): 1092-1098.

Arslan U, Turkoglu S, Balcioglu S, Tavil Y, Karakan $T$ and Cengel A. (2007): Association between nonalcoholic fatty liver disease and coronary artery disease. Coron Artery Dis., 18 (6): 433-436.

Ascha MS, Hanouneh IA, Lopez R, Tamimi TA, Feldstein AF and Zein NN. (2010): The incidence and risk factors of hepatocellular carcinoma in patients with nonalcoholic steatohepatitis. Hepatology, 51(6): 1972-1978.

Atta A, Elkoly T, Mouneir S, Gehan K, Alwabe I and Shaimaa $Z$ (2010): Hepatoprotective effect of methanol extract of Zingiber officinale and Cichorium intybus. Indian Journal of Pharmaceutical Sciences, 72: 564-570.

Breuer J (1996): Report on the symposium drug effects in clinical chemistry methods. Eur. J. Clin. Chem. Clin. Biochem., 34: 385-386.

Burstein M (1970): Rapid method for isolation of lipoproteins from human serum by precipitation with poly-anion. J. lipid Research, 11: 583-588.

Doumas BT (1975): Standards for Total Serum Protein Assays - A Collaborative Study. Clin. Chem., 21(8): 1159-1166.

Dumas BT, Watson WA and Biggs HG (1997): Albumin standards and the measurement of serum albumin with bromcresol green. Clin. Chim. Acta, 258 (1): 21-30.

Fortin F (2004): Protection against cocarcinogenesis by antioxidants. Editorial Director. The Visual Foods Encyclopedia. Macmillan, New York. 22:116.

Fossati P and Prencie L (1982): Serum triglycerides determined colorimeterically with an enzyme that produces hydrogen peroxide. Clin. Chem., 28: 20772080.

Friedewald T, Levy $R$ and Fredrichsor D (1972): Estimation of the concentration of low-density lipioprotein cholesterol in plasma without use of the preparative ultracentrifuge. Clin. Chem., 18: 499-502. Gazzani G, Daglia M, Papetti A and Gregotti C (2000): In vitro and in vivo anti-and prooxidant components of cichorium intybus. J. Pharm. Biomed. Anal., 23 (1): 127-133.

Gürbüz I, Üstün O, Yeilada E, Sezik $E$ and Akyürek N (2002): In vivo gastroprotective effects of five Turkish folk remedies against ethanol-induced lesions. J. Ethnopharmacol., 83 (3): 241-244.

Harris H (1900): After Bruse, Casselman. W. G. (1959): Histochemical technique by Methuan and Co. LTD. London. Pp: 205-209.

Henry R, Cannon D and Winkelman J (1974): Clinical Chemistry Principles and Techniques, Harper and Row. New York, Pp: 1440-1452.

Jaffe M (1986): Quantitative colorimetric determination of creatinine in serum or urine. $\mathrm{Z}$. Physiol. Chem., 10: 391-400.
Kalantari H and Rastmanesh M (2009): Protective property of Cichorium intybus in $\mathrm{CCl}_{4}$ induced liver damage in mice. Arch. Iran Med., 3: 46- 47.

Kaplan A (1984): Quantitative determination of total lipids. Clin. Chem., 22: 919-932.

Keys A (1980): Alpha lipoprotein (HDL) cholesterol in the serum and the risk of coronary heart disease and death. Lancet, 2: 603-608.

Kim J, Mun W, Jeon K and Park J (2002): Effects of the ethanol extract of Cichorium intybus on the immunotoxicity by ethanol in mice. Int. Immunopharm., 2 (6): 733-744.

Kim M and Shin HK (1998): The water-soluble extract of chicory influences serum and liver lipid concentrations, cecal short-chain fatty acid concentrations and fecal lipid excretion in rats. J. Nutr., 128 (10): 1731- 1736.

Kocsis I, Hagymàsi Á, Kéry E, Szôke E and Blàzovics A (2003): Effects of chicory on pancreas status of rats in experimental dislipidemia. Acta Biologica Szegediensis, 47: 143-146.

Krylova S, Efimova L and Zueva E (2006): The effect of Cichorium root extract on the morphofunctional state of liver in rats with $\mathrm{CCL}_{4}$ induced hepatitis model. Eksp. Klin. Farmacol., 69: 34-36. Kulkarni A and Byczkowski J (1994): Hepatotoxicity. In: Introduction to Biochemical Toxicology, Hodgson E. and Levi P, Pp: 459-490, Appleton and Lange, Norwalk, CT.

Letteron P, Sutton A, Mansouri A, Fromenty B and Pessayre D (2003): Inhibition of microsomal triglyceride transfer protein: Another mechanism for drug-induced steatosis in mice. Hepatology, 38: 133140.

Lu F (1996): Toxicology of liver. In: Basic Toxicology. Fundamentals Target organs and risk assessment. Lu F, Washinton DC: Taylor and Francis, $3^{\text {rd }}$ ed., 177- 188

Meehye K and Hyun K (1998): The water-soluble extract of chicory influences serum and liver lipid concentrations, cecal short-chain fatty acid concentrations and fecal lipid excretion in rats. J. Nutr., 128 (10): 1731- 1736.

Mitra S, Venkataranganna M, Gopumadhavn, S, Anturlikar S and Udupa U (2001): The protective effect of HD-03 in $\mathrm{CCL}_{4}$-induced hepatic encephalopathy in rats. Phytotherp. Res., 15: 493496.

Najafzadeh $H$, Ghadrdan A, Jalali $M$ and Alizadeh F (2011): Evaluation of changes of factors related to liver function in serum of horse by administration of Cichorium intybus. International Journal Animal Veterinary Advances, 3 (1): 1- 5.

Narinder $K$ and Anil K (2002): Effect of a longchained fructan raftiline HP on blood lipids and spontaneous atherosclerosis in low density receptor knockout mice. Nutrition Research, 22 (4): 473-480.

Nicola W, Ibrahim $K$, Mikkail T, Girgis $\mathbf{R}$ and Khadr M (1996): Role of hypoglycemic plant extract cleom droserifolia in improving glucose and lipid metabolism and its relation to in insulin resistance in fatty liver .Boll. chem. farmacutica., 135 (9): 507517. 
Patton C and Crouch S (1977): A colorimetric method for the determination of blood urea concentration. J. Anal. Chem., 49: 464-469.

Persijn JP and Slik W (1976): A new method for the determination of gamma-glutamyltransferase in serum. J. Clin. Chem. Clin. Biochem., 14 (9):421427.

Petlevski R, Hadzija M, Slijepcevic M, Juretic D and Petrik J (2003): Glutathione S-transferase and malondialdehyde in the liver of mice after short term treatment with plant mixture extract. Phytotherap. Res., 17: 311-314.

Petrovic J, Stanojkovic A, Comic J and Curcic S (2004): Antibacterial activity of Cichorium intybus. Fitoterapia, 75 (7-8): 737- 739.

Plaa G and Hewitt W (1982): Detection and evaluation of chemically induced liver injury. In: Principles and Methods of Toxicology. Raven Press, Pp: 407-445.

Pushparaj P, Low H, Manikandan J, Tan B and Tan C (2007): Anti-diabetic effects of Cichorium intybus in streptozotocin-induced diabetic rats. J. Ethnopharmacol., 111 (2): 430- 434.

Reddy J and Rao M (2006): Lipid metabolism and liver inflammation. II. Fatty liver disease and fatty acid oxidation. Am. J. Physiol. Gastrointest. Liver Physiol., 290 (5): 852-858.

Reed D (1994): Mechanism of chemically induced cell injury and cellular protection mechanisms. In: introduction to Biochemical Toxicology, Hodgson E. and Levi P, Connecticut: Applrton and Lange $2^{\text {nd }}$ ed., Pp: 265-295.

Rossetto M, Lante A, Vanzani P, Spettoli P, Scarpa $M$ and Rigo A (2005): Red chicory as potent scavenger of highly reactive radicals. A study on their phenolics composition and peroxyl radical trapping capacity and efficiency. J. Agric. Food Chem., 53: 8169- 8175.

Roushdy H, El-Hussaini $M$ and Saleh F (1989): Effect of whole-body gamma-irradiation and/or dietary protein deficiency on levels of plasma nonprotein-nitrogen and amino acids in desert rodents and albino rats. Egypt. J. Rad. Sci. Applic., 1: 156166.
Sarawathy S and Devi C (2001): Modulating effect of an ayurvedic formulation on antituberculosis drug induced alterations in rat liver microsomes. Phytotherap. Res., 15: 501-505.

Snedecor G and Cochran W (1980): Statistical methods. Oxford and J. B. H. Publishing Co., $7^{\text {th }}$ ed. Stacey N, Haschek W and Winder C (1993): Systemic toxicology. In: Occupational Toxicology. Statacey N and Londom: Taylor and Francis Ltd, $2^{\text {nd }}$ ed., Pp: 37-76.

Storozhuk P and Shamsutdinova V (1981): Effect of certain antibiotics of tetracycline series on the level of blood sugar and the role of insulin in the mechanism of its regulation. Probl. Endokrinol., 22 (6): 106-110.

Suchalatha S and Shyamala C (2004): Effect of arogh -apolyherbal formulation on the marker enzymes in isoproterenol induced myocardial injury. Indian Journal Clinical Biochemistry, 19 (2): 184189

Tietz P (1986): Textbook of clinical chemistry. W.B. Saunders Co., London, Pheladelphia, P. 796.

Wight $W$ and Niekerk J (1983): Determination of reducing sugars, sucrose and insulin. J. Agric. Food Chem., 31: 282-285

Wong VW, Wong GL, Choi PC, Chan AW, Li MK, Chan HY, Chim AM, Yu J, Sung JJ and Chan HL. (2010): Disease progression of non-alcoholic fatty liver disease: a prospective study with paired liver biopsies at 3 years. Gut., 59 (7): 969-974.

Yassin $M$ and El-Hadidy $E$ (2007): Antioxidants content of chicory leaves extract and its effect as hypolipidemic agent in experimental rats. Ann. Agric. Sci., 52: 177186.

Zafar $R$ and Mujahed A (1998): Antihepatotoxic effects of root and root callus extracts of Chicorium intybus L. J. Ethnopharmacol., 63 (3): 227- 231 


\section{تاثير الشيكوريا على الكبد الدهنى المستحدث بواسطة مركب الأوكسى تتراسيكلين فى الجرذان.}

*ايمان جمال الدين عزت هلال، *سامية محمد عبد الوهاب ، **عاطف محمد موسى شرف، *غادة عادل زيدان

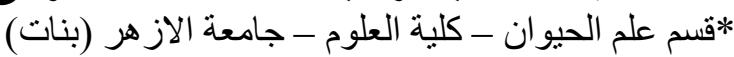

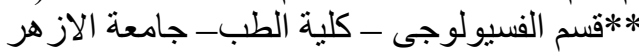

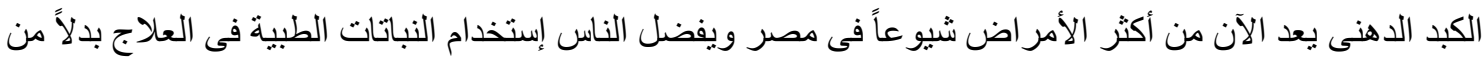

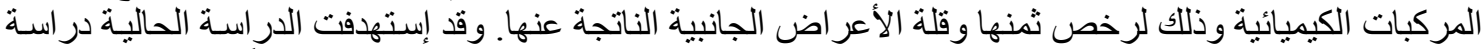

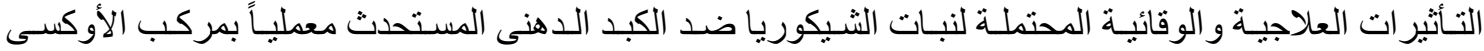
تتر اسيكلين وذلك لمحاولة فهم آلية عمل هذا النبات والتى قد تمهد الطريق لتطبيقات علاجية ممكنة.

تم تقسيم الحيو انات إلى مجمو عتين رئيسيتين، كل مجمو عة تحتوى على 15 عينة:

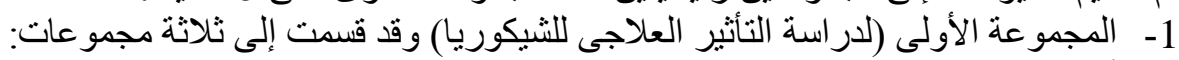

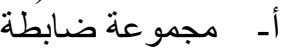

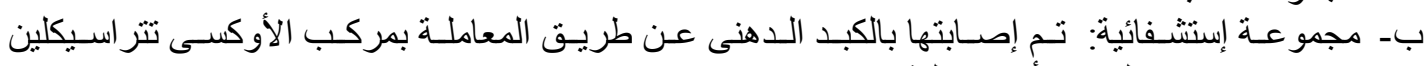
(120)مجم/كجم ) لمدة 3 أيام متتالية. ج- مجمو عة علاجية: تم معاملتها بمستخلص نبات الثيكوريا (70مجم/كجم) لمدة 30 يوم بعد إصـابتها بالكبد

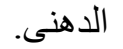
جميع الحيو انات تم ذبحها بعد 33 يوم من بدء التجربة. 2- المجمو عة الثانية (لدر اسة التأثير الوقائى للشيكوريا) وقد قسمت إلى ثلاثثة مجمو عات:

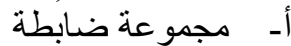
بـ مجمو عة مصابة بالكبد الدهنى: عن طريق المعاملة بمركب الأوكسى تتر اسيكلين (120مجم/كجم ) لمدة 3 ج- مجمو عة وقائية: تم معاملتها بمستخلص نبات الثيكوريا (70مجم/كجم) لمدة 15 يوم قبل إصـابتها بالكبد

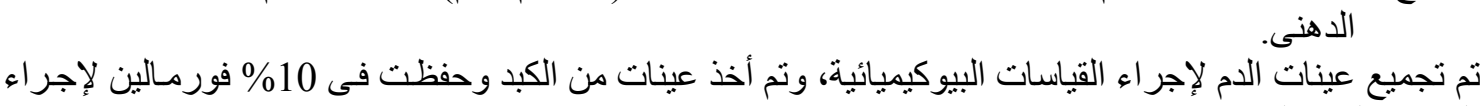

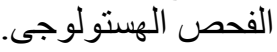

أظهرت المجموعات المصـابة بالكبد الدهنى زيادة ملحوظة فى مسنتوى الجلوكوز بالدم، الكوليستيرول، الدهون

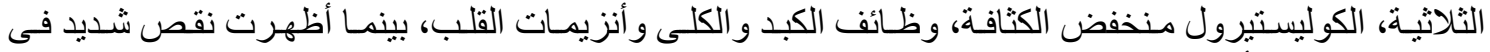

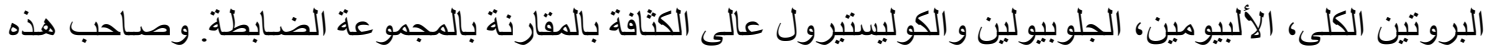

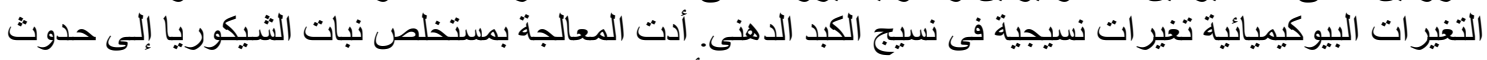

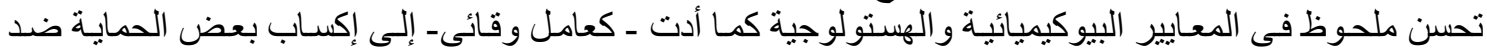

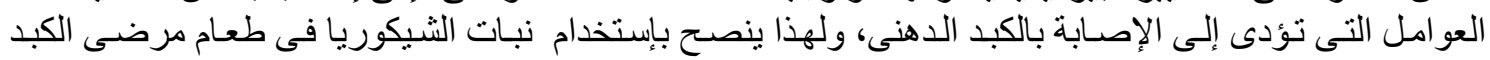

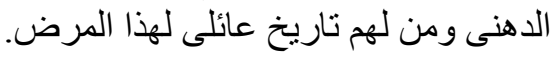

